\title{
H2AC15 wt Allele
}

National Cancer Institute

\section{Source}

National Cancer Institute. H2AC15 wt Allele. NCI Thesaurus. Code C162903.

Human H2AC15 wild-type allele is located 6p22.1 and is approximately $1 \mathrm{~kb}$ in leng th. This allele, which encodes histone H2A type 1 protein, is involved in histone-mediated nucleosome assembly. 